\title{
COMPARATIVE STUDY OF EFFECT OF CAUDAL MORPHINE AND FENTANYL ADDED TO ROPIVACAINE IN PAEDIATRIC INFRAUMBILICAL SURGERY
}

Swastika Swaro ${ }^{1}$, Swarna Banerjee 2 , Debasis Kuanar ${ }^{3}$, Daisy Karan 4

${ }^{1}$ Assistant Professor, Department of Anaesthesiology, IMS \& SUM Hospital.

${ }^{2}$ Assistant Professor, Department of Anaesthesiology, IMS \& SUM Hospital.

${ }^{3}$ Assistant Professor, Department of Anaesthesiology, IMS \& SUM Hospital.

${ }^{4}$ Assistant Professor, Department of Anaesthesiology, IMS \& SUM Hospital.

\section{ABSTRACT}

\section{BACKGROUND}

Caudal analgesia is a very popular route to provide postoperative analgesia in children because of simple technique, high success rate and smooth recovery. Various additives have been used to increase the duration provided by ropivacaine administered by a single shot caudal injection.

\section{METHODS}

A prospective, randomised double blind controlled study in 40 ASA Grade 1 children aged 1-6 years undergoing subumbilical surgery was conducted. Patients were divided into 2 groups to receive either fentanyl $2 \mu \mathrm{gs} / \mathrm{kg}$ (FR) or morphine $20 \mu \mathrm{gs} / \mathrm{kg}$ (MR) in ropivacaine $0.2 \%(1 \mathrm{~mL} / \mathrm{kg})$ for caudal analgesia. The duration of analgesia (FLACC scale), sedation and side effects were observed.

\section{RESULT}

The mean duration of analgesia was 10.42 (0.89) hour in MR group compared to 5.78 (0.87) hour in FR group (P, 0.0001). Subjects in MR group remained more sedated than FR group. Vomiting was observed in $15 \%$ and $10 \%$ in MR and FR group respectively. Itching was 15\% and 5\% in MR and FR group respectively. No hypotension, bradycardia or respiratory depression was observed in any subject.

\section{CONCLUSION}

Caudal morphine $20 \mu \mathrm{gs} / \mathrm{kg}$ in ropivacaine $0.2 \%$ provides longer duration of analgesia and sedation compared to caudal fentanyl $2 \mu \mathrm{g} / \mathrm{kg}$ in ropivacaine $0.2 \%(1 \mathrm{~mL} / \mathrm{kg})$ without any significant side effect in children in subumbilical surgery.

\section{KEYWORDS}

Caudal Anaesthesia, Ropivacaine, Morphine, Fentanyl, Postoperative Analgesia.

HOW TO CITE THIS ARTICLE: Swaro S, Banerjee S, Kuanar D, et al. Comparative study of effect of caudal morphine and fentanyl added to ropivacaine in paediatric infraumbilical surgery. J. Evolution Med. Dent. Sci. 2016;5(22):1143-1145,

DOI:10.14260/jemds/2016/266

\section{INTRODUCTION}

Caudal epidural block is one of the most common regional anaesthesia technique used for intraoperative and postoperative analgesia because of its simple technique, high success rate, smooth recovery and predictable level of block. It is used mainly in perineal and subumbilical procedures.(1)

Caudal epidural block, however, has the disadvantage of having shorter duration of action even when long-acting local anaesthetics are used. There is an increasing concern regarding the use of caudal catheter to administer repeated doses or infusion due to risk of infection. So to improve duration of anaesthesia and quality of analgesia of a single shot caudal, various additives have been used such as opioids, clonidine, neostigmine with their associated side effects. $(2,3)$

Bupivacaine was a popular drug in regional anaesthesia for years until toxic reactions were noted. Ropivacaine produces less motor blockade, less cardiovascular and neurological toxicity making it suitable for day care surgery in children. ${ }^{(4,5,6,7)}$

Financial or Other, Competing Interest: None.

Submission 30-01-2016, Peer Review 28-02-2016,

Acceptance 04-03-2016, Published 15-03-2016.

Corresponding Author:

Dr. Swastika Swaro,

Assistant Professor, IMS \& SUM Hospital,

Bhubaneswar.

E-mail: drswastika81@yahoo.com

DOI: $10.14260 /$ jemds/2016/266
We therefore designed a prospective randomised, double blind study to compare the duration of analgesia, sedation and side effects, if any of single shot caudal morphine or fentanyl in ropivacaine $0.2 \%$ in paediatric patients undergoing subumbilical procedures.

\section{MATERIAL AND METHODS}

The study was conducted from June 2015 to December 2015. After having the written informed consent from parents, the patients were randomly divided into 2 groups double blindly. All children were ASA Grade 1 between ages 1-6 years undergoing subumbilical procedures. Exclusion criteria include a history of developmental delay or mental retardation, which could make observation of pain intensity assessment outside the norm, coagulopathy, any sacral abnormality or infection at the site of block or known allergy to the study drugs.

Patients were kept fasting as per ASA guidelines (Clear liquid 2 hours, breast milk 4 hours, infant formula, non-human milk and light meal 6 hours). All routine monitors including NIBP, pulse oximetry and ECG were attached. The patients were premeditated with Glycopyrrolate $(0.04 \mathrm{mg} / \mathrm{kg})$ and Inj. Fentanyl $1 \mu \mathrm{gs} / \mathrm{kg}$. General anaesthesia was induced with sevoflurane in oxygen/propofol ( $2 \mu \mathrm{gs} / \mathrm{kg}$ ) depending on the presence of IV cannula. Appropriate size of Proseal LMA was given after giving Injection atracurium $0.5 \mathrm{mg} / \mathrm{kg}$. A suction catheter was kept for nasogastric aspiration. Depth of anaesthesia was maintained with isoflurane, atracurium, 
$\mathrm{N}_{2} \mathrm{O}: \mathrm{O}_{2}(1: 1)$. After this, patient was positioned in lateral decubitus and a single dose caudal block was performed under all aseptic conditions using $23 \mathrm{G}$ needle. Placement of needle was confirmed by characteristic pop of sacrococcygeal ligament penetration followed by whoosh test with $0.5 \mathrm{~mL}$ air.(8) after negative aspiration, patients in the group MR received Morphine $20 \mu \mathrm{gs} / \mathrm{kg}$ with ropivacaine $0.2 \% 1 \mathrm{~mL} / \mathrm{kg}$, whereas patients in the group FR received fentanyl $2 \mu \mathrm{gs} / \mathrm{kg}$ with ropivacaine $0.2 \% 1 \mathrm{~mL} / \mathrm{kg}$.

RL was used as maintenance fluid. Intraoperative $\mathrm{BP}$, pulse, $\mathrm{SPO}_{2}, \mathrm{ETCO}_{2}$, ECG were monitored and recorded. Injection ondansetron IV $0.08 \mathrm{mg} / \mathrm{kg}$ was administered before reversal with Glycopyrrolate and neostigmine. After extubation patients were shifted to PACU where they were capable of maintaining a patent airway and observation of $\mathrm{HR}$, $\mathrm{SPO}_{2}$. ECG could be done.

Using FLACC pain scale with 0-10 score range, patients' pain intensity was assessed.(9) by a resident doctor (Blinded to the treatment). The sedation score was assessed by four-point scale. Pain and sedation was observed every hour. A note was made for any side effect nausea, vomiting, itching, bradycardia ( $\mathrm{HR}<60 / \mathrm{min}$ ), hypotension (BP $<20 \%$ of the baseline) and respiratory depression (SPO2 $<95 \%$ ). The duration of sedation was measured as the time from drug administration to a score of $\leq 2$. The duration of analgesia was measured as the time from drug administration to a FLACC of $\geq 4$. At this point, paracetamol suppository $40 \mathrm{mg} / \mathrm{kg}$ was given as rescue analgesia

\begin{tabular}{|c|c|}
\hline Score & Response of Patients \\
\hline 1. & Alert and aware \\
\hline 2. & Asleep, arousable by verbal contact \\
\hline 3. & Asleep, arousable by physical contact \\
\hline 4. & Sleep not arousable \\
\hline \multicolumn{2}{|c|}{ Table 1: Sedation Score } \\
\hline
\end{tabular}

\section{RESULT}

Forty ASA1 patients aged 1-6 years undergoing elective subumbilical surgeries were enrolled for this prospective randomised double blind study. All the subject characteristics are documented in register and Microsoft excel sheet (Table 2). All caudal blocks were regarded as clinically successful. The total duration of analgesia (For FLACC $\geq 4$ ) was $10.42 \pm 0.89$ hours in MR group as compared to $5.78 \pm 0.87$ hours in FR group. The total duration of sedation was $3.49 \pm 0.52$ hours in MR group as compared to $1.272 \pm 0.38$ hours in FR group. After comparing between these two groups with the help of ' $t$ ' test, it was found that there was statistically significant prolonged duration of analgesia and sedation in MR group ( $\mathrm{p} \leq 0001$ ). Vomiting was observed in $15 \%$ and $10 \%$ patients in MR and FR group respectively. Itching was found in $15 \%$ and $5 \%$ patients in MR and FR group respectively. No hypotension, bradycardia or respiratory depression was observed in any subject.

\begin{tabular}{|c|c|c|c|}
\hline & Group MR (n=20) & Group FR (n=20) & P Value \\
\hline Age (years) & $3.17 \pm 1.35$ & $3.03 \pm 1.32$ & 0.74 \\
\hline Weight (Kg) & $12.37 \pm 3.22$ & $12.71 \pm 2.87$ & 0.73 \\
\hline Duration of Surgery (hrs) & $1.01 \pm 0.47$ & $1.04 \pm 0.49$ & 0.83 \\
\hline Type of Surgery & $5(25 \%)$ & $6(30 \%)$ & \\
Circumcision & $5(25 \%)$ & $4(20 \%)$ & \\
Orchidopexy & $5(25 \%)$ & $6(30 \%)$ & \\
Inguinal Herniotomy & $5(25 \%)$ & $4(20 \%)$ & \\
Hypospadias & Table2: Subject Characteristics-Demographic and Operative Data \\
\hline \multicolumn{2}{|c|}{ (MR-Morphine Ropivacaine Group, FR-Fentanyl Ropivacaine Group) } \\
\hline
\end{tabular}

Values are expressed as mean \pm SD. No significant differences between two groups ( $>>0.05)$. SD: Standard Deviation

\begin{tabular}{|c|c|c|c|}
\hline & $\begin{array}{c}\text { Group MR } \\
(\mathbf{n = 2 0})\end{array}$ & $\begin{array}{c}\text { Group FR } \\
(\mathbf{n = 2 0})\end{array}$ & $\begin{array}{c}\text { P } \\
\text { Value }\end{array}$ \\
\hline $\begin{array}{c}\text { Duration of } \\
\text { analgesia(hrs) }\end{array}$ & $10.42 \pm 0.89$ & $5.78 \pm 0.87$ & 0.0001 \\
\hline $\begin{array}{c}\text { Duration of } \\
\text { sedation(hrs) }\end{array}$ & $3.49 \pm 0.52$ & $1.272 \pm 0.38$ & 0.0001 \\
\hline Vomiting & $3(15 \%)$ & $2(10 \%)$ & 0.64 \\
\hline Itching & $3(15 \%)$ & $1(5 \%)$ & 0.30 \\
\hline Bradycardia & 0 & 0 & \\
\hline Hypotension & 0 & 0 & \\
\hline $\begin{array}{c}\text { Respiratory } \\
\text { depression } \\
\text { (spo2<95\%) }\end{array}$ & 0 & 0 & \\
\hline \multicolumn{3}{|c|}{ Table 3: Duration of Analgesia, Sedation and Side } \\
Effects
\end{tabular}

Values are expressed as Mean \pm SD. No significant differences between two groups $(\mathrm{p}>0.05)$. SD: Standard Deviation.

\section{STATISTICAL ANALYSIS}

Data were analysed using computer statistical software system SPSS version 20. The data was expressed as mean \pm standard deviation as appropriate.
Patient's characteristics and duration of sedation and analgesia were compared using unpaired t-test. $\mathrm{P} \leq 0.05$ was considered to be statistically significant.

\section{DISCUSSION}

Postoperative pain starts with surgical trauma and ends with tissue healing. Relief of pain in paediatric patients demands relatively safer techniques and drugs. Caudal epidural analgesia is a simple, frequently used technique which provides effective analgesia for both intraoperative and postoperative purposes in paediatric patients for infraumbilical surgeries.

Ropivacaine is a relatively safe local anaesthetic with a better safety margin and separation of sensory and motor effects. Bosenberg A et al. demonstrated that ropivacaine $0.2 \%$ ( $2 \mathrm{mg} / \mathrm{mL}$ ) for caudal block provide satisfactory postoperative pain relief after inguinal surgery in 4-12 years' children. It also showed ropivacaine $1 \mathrm{mg} / \mathrm{mL}$ had less efficacy, while use of $3 \mathrm{mg} / \mathrm{mL}$ was associated with higher incidence of motor block with minimal improvement in postoperative pain relief.(10) 
Use of ropivacaine in paediatric caudal blocks has been reported by G. Ivani et al. who used $0.2 \%$ ropivacaine $2 \mathrm{mg} / \mathrm{mL}$ $(1 \mathrm{~mL} / \mathrm{kg})$ via caudal route for children aged 1-10 years. Addition of adjuvants allows use of lower concentration of local anaesthetic agents and also improved analgesic effect. Various agents used for adjuvant are clonidine, dexamethasone, dexmedetomidine, opioids (Fentanyl, morphine), midazolam, ketamine.(11) Fentanyl is one of the most commonly used adjuvants with local anaesthetic agents for caudal block.(12) Study by Elham et al. which compared caudal fentanyl to caudal dexmedetomidine and dexamethasone when added to local anaesthesia bupivacaine concluded that caudal fentanyl had a very short duration of action with mean duration of $330.4 \pm 14.7$ minutes $(\mathrm{P}<0.001)$.(13) Study by Campbell et al. compared caudal fentanyl $(1 \mu / \mathrm{kg})$-bupivacaine $(0.25 \%)$ to that of bupivacaine alone also concluded having no added advantage of improved or prolonged postoperative analgesia of adding fentanyl at dose $1 \mu / \mathrm{kg}$.(14) Adding drugs to ropivacaine can prolong its analgesic efficacy.

MK Arora et al. have shown low dose morphine $[0.03$ $\mathrm{mg} / \mathrm{kg}$ ) when added to $0.25 \%$ bupivacaine significantly improved quality as well as duration of analgesia after urogenital, orthopaedic and lower abdominal general surgical procedures in children between 1-8 years.(15) Mayhew et al. showed that low dose caudal morphine $0.03-0.04 \mathrm{mg} / \mathrm{kg}$ had relief of postoperative pain in children.(16) Duration of analgesia was between 6-24 hours. There was no respiratory depression noted in 500 cases. Hence, a dose of fentanyl 2 $\mu \mathrm{g} / \mathrm{kg}$ and morphine $20 \mu \mathrm{g} / \mathrm{kg}$ added to $0.2 \%$ ropivacaine (1 $\mathrm{mL} / \mathrm{kg}$ ) individually was chosen as study drug dose in FR and MR group respectively. Demographic data reveals that the two groups are comparable. It was observed that addition of morphine to ropivacaine significantly improved the quality as well as duration of analgesia when compared to fentanyl in children aged 1-6 years.

Duration of analgesia in the present study in MR group was found to be $10.42(0.89) \mathrm{hrs}$. This correlates to study of MK Arora et al. who reported the mean duration of analgesia after caudal block using bupivacaine and morphine $(0.03 \mathrm{mg} / \mathrm{kg})$ was $12-26 \mathrm{hrs}$ with a mean duration of (20.8 $\pm 3-4 \mathrm{hrs})$. The duration of analgesia in our study in FR group was found to be $5.78(0.87) \mathrm{hrs}$. This correlates to study of Campbell et al. who concluded that adding fentanyl to bupivacaine does not produce added advantage of prolonging the block. No serious side effects like respiratory depression or apnoea was seen in any of the groups. Vomiting was found 15\% in MR group and $10 \%$ in FR group. This corresponds to the study of MK Arora et al. who reported nausea and vomiting after use of morphine with bupivacaine for caudal block. Constant et al. compared caudal clonidine and fentanyl, which showed adverse effect especially vomiting occurred more in fentanyl group.(17)

\section{CONCLUSION}

Addition of morphine to ropivacaine as caudal analgesia provides prolonged postoperative analgesia and sedation than fentanyl addition to ropivacaine. Vomiting and itching was little more in morphine group, but it is not statistically significant. Hemodynamically, both groups are stable.

\section{REFERENCES}

1. Dalens B. Nociception and pain, In Dalens B (Ed), Regional anaesthesia in infants, children and adolescents. 19 London: Williams and Wilkins p-35.

2. Cook B, Doyle E. The use of additives to local anaesthetic solutions for caudal epidural blockade. Paediatr Anaesth 1996;6:353-9.

3. Abdulatif M, El-Sanabary M. Caudal neostigmine, bupivacaine and their combination for postoperative pain management after hypospadias surgery in children. Anaesth Analg 2002;95(5):1215-8.

4. Reiz S, Häggmark S, Johansson G, et al. Cardiotoxicity of ropivacaine: a new amide local anaesthetic agent. Acta Anaesthesiol Scand 1989;33(2):93-8.

5. Knudsen K, Beckman Sukula M, Blomberg S, et al. Central nervous and cardiovascular effects of IV infusions of ropivacaine, bupivacaine and placebo in volunteers. Br J Anaesth 1997;78(5):507-14.

6. Scott DB, Lee A, Fagan D, et al. Acute toxicity of ropivacaine compared with that of bupivacaine. Anaesth Analg 1989;69(5):63-9.

7. Mc Clure JH. Ropivacaine. Br J Anaesth 1996;76:300-307.

8. Lewis MP, Thomas P, Wilson LF, et al. The 'whoosh' test: a clinical test to confirm correct needle placement in caudal epidural injections. Anaesthesia 1992;47(1):5758.

9. Merkel SI, Voepel-Lewis T, Shayevitz JR, et al. The FLACC: a behavioural scale for scoring postoperative pain in young children. Paediatr Nurs 1997;23(3):293-7.

10. Bosenberg A, Thomas J, Lopez T, et al. The efficacy of caudal ropivacaine1, 2, $3 \mathrm{mg}$ for postoperative analgesia in children. Paediatric Anaesthesia 2002;12(1):53-8.

11. Lonnqvist PA. Adjuncts to caudal block in children -Quo vadis? Br J Anaesthesia 2005;95(4):431-433.

12. Saunders JC. Paediatric regional anaesthesia, a survey of practice in the United Kingdom. Br J Anaesthesia 2002;89(5):707-10.

13. Elham M EL-Fekes, Ahmed A. Fentanyl, dexmedetomidine, dexamethasone as adjuvant to local anaesthesia in caudal analgesia in paediatric patients. Egyptian journal of anaesthesia 2015;31:175-180.

14. Campbell FA, Fear DW. Analgesic efficacy and safety of a caudal bupivacaine-fentanyl mixture in children. Can J Anaesthesia 1992;39:661-664.

15. Arora, Rajeswari S, Haul HL. Comparison of caudal bupivacaine and morphine for relief of postoperative pain in children. Journal of Indian association of paediatric surgery 2004;9.

16. Mayhew JF, Brodsky RC, Blakey D, et al. Low dose caudal morphine for perioperative analgesia in infants and children: a report of 500 cases. Journal of clinical anaesthesia 1995;7(8):640-42.

17. Constant I, Gall O, Gouyet I, et al. Comparison of caudal clonidine and fentanyl added to local anaesthesia prolongs duration of surgical analgesia after single shot caudal block in children. Br J Anaesth 1998;(80):294-8. 